Environment Conservation Journal 14(1\&2) 97-101, 2013

ISSN 0972-3099 (Print) 2278-5124 (Online)

Abstracted and Indexed

\title{
Antibacterial activity of Terminalia chebula Retz., against Escherichia coli
}

\author{
Nisha Sharma $\bowtie$ and Purshotam Kaushik
}

Received:12.02.2013

Revised: 16.03.2013

Accepted: 21.04.2013

\begin{abstract}
Terminalia chebula Retz. belongs to the family Combretaceae and is commonly known as Black myrobalan. In the present study fruits of Terminalia chebula were screened for potential antibacterial activity against Gram-negative bacterial strain Escherichia coli. The antibacterial activity was determined in aqueous, methanol, ethanol and acetone extracts by using disc diffusion ( Kirby-Bauer) method. The activity was carried out for different concentrations of plant extracts i.e. 100,200 and $400 \mathrm{mg} / \mathrm{ml}$ and the relative solvents were used as control for respective extracts. Ciprofloxacin was used as positive control. The antibacterial activity of Terminalia chebula gave encouraging results.
\end{abstract}

Keywords Antibacterial, Terminalia chebula, Escherichia coli, Black myrobalan

\section{Introduction}

Escherichia coli is one of the bacterial species found in normal microflora of the digestive tract. However, after 1940, the E.coli strains have been reported to cause several diseases, one of which was E.coli enteropathogenic (EPEC) (Nataro and Kaper, 1998). EPEC is the most frequent cause of diarrhoea in babies and infants all over the world in general and in developing countries like Indonesia in particular and South East Asia and cause infection by way of adhesion with the receptor present on the host cell surface, like in the ileum part of intestine epithelial cell. Adhesion is a factor of bacteria virulence carried out by the adhesion protein present in pilli and outer membrane protein (OMP) of bacteria. Bacterial adhesion on the tissue can determine the microorganism colonization capability (Surono, 2004). According to Todar (2008) bacterial adhesion which is followed by the occurrence of colonization in the sensitive host is an important factor and is needed to start the pathogenesis of diseases.

The Herbals have become increasingly popular and their use is wide spread clear-cut proof of their efficacy on microorganisms inducing pathogens is yet to be explored. Various medicinal plants have been used for years in daily life to treat diseases all over the world.

\section{Author's Address}

Department of Botany and Microbiology,

Gurukul Kangri University, Haridwar (U.K.), India.

E-mail: ns66371@gmail.com

Copyright by ASEA

All rights of reproduction in any form reserved
Higher plants as source of medicinal compounds have continued to play a dominant role in the maintenance of human health since ancient times over $50 \%$ of all modern clinical drugs are of natural product origin and natural products play an important role in drug development programs in the pharmaceutical industry. It has been suggested that aqueous and ethanolic extracts from plants used in allopathic medicine are potential sources of antiviral, antitumoural and antimicrobial agents (Farombi, 2003). Terminalia chebula plant has been selected to determine its antibacterial property. The study looks into the in vitro antibacterial activity of this plant with different solvent extracts against Gram-negative pathogenic bacterium E.coli that causes the most common cases of infectious diseases.

\section{Material and Methods \\ Collection and Identification of plant material}

The dried fruits of Terminalia chebula were collected from VHCA, Karnal and identified by using standard floras like 'The Flora of British India' (J.D. Hooker ) and compared with standard voucher specimens of herbarium.

\section{Preparation of Plant extracts} Aqueous extract

$50 \mathrm{~g}$ of powdered plant material was mixed well in $500 \mathrm{ml}$ distilled water with continuous stirring for 
30 minutes. The solution was kept at room temperature for at least 24 hours and then filtered using muslin cloth. The supernatant was again filtered using Whatman filter paper No.1 under strict aseptic conditions. Then the extract was evaporated to dryness at its boiling temperature of $100{ }^{\circ} \mathrm{C}$. The extract was collected in fresh sterilized glass vials and stored at $4{ }^{\circ} \mathrm{C}$ until use (Akueshi et al., 2002). Aqueous extract was prepared in concentration of 100,200 and $400 \mathrm{mg} / \mathrm{ml}$ by dissolving the extract in distilled water.

\section{Organic Solvent Extraction}

The dried plant material was pulverized into fine powder using a grinder (mixer). About $50 \mathrm{~g}$ of powdered material was extracted in Soxhlet extraction apparatus with $500 \mathrm{ml}$ of each of the following solvents; methanol, ethanol and acetone The extracts obtained with each solvent were filtered through Whatman filter paper No. 42 and the respective solvents were evaporated (at $40{ }^{\circ} \mathrm{C}$ ) with the help of heating mantle. The sticky dark coloured substances were obtained and stored in refrigerator for prior to use following Beyer and Walter (1997); Dhale and Markandeya (2011) and Acharyya et al., (2009). For antibacterial analysis different concentrations of extracts viz., 100, 200, $400 \mathrm{mg} / \mathrm{ml}$ were prepared by dissolving the residues in the respective solvents. Extracts were stored in glass vials at $4^{0} \mathrm{C}$ for further use.

\section{Collection of Bacterial culture}

The test organism Escherichia coli (MTCC 723) culture was procured from IMTech, Chandigarh and maintained on nutrient agar slants.

\section{Antibacterial Susceptibility Assay}

In vitro antibacterial activity of afore said crude extracts of selected medicinal plants was evaluated using the disc diffusion method of Bauer et al.,(1966). $100 \mu 1$ of each bacterial culture (which has been adjusted to $0.5 \mathrm{McF}$ arland standard), was used to lawn Muller Hinton agar plated evenly using a sterile spreader. The plates were dried for 15 minutes and then used for the sensitivity test. The discs with different concentrations $(100,200$ and $400 \mathrm{mg} / \mathrm{ml}$ ) of plant extracts were placed on the Muller-Hinton agar surface. The solvent loaded disc without extracts in it served as negative control in the study. The four discs were placed in each test plate, one of which was negative control and three were treated ones. The negative control was pure solvent of respective plant extract. Besides, the controls, each plate had three treated discs placed at equidistance to each other. The plate was then incubated at $37^{0} \mathrm{C}$ for 18 to 24 hours. After the incubation, the plates were examined for inhibition zone. The inhibition zone was then measured in millimeters using transparent scale of Hi-media. All tests were performed in sterile condition and repeated three times to ensure reliability (Erturk et al., 2003; Ncube et al., 2008; Segni et al., 2011).

\section{Minimum inhibitory Concentration} Determination by broth micro dilution method Minimum inhibitory concentration (MIC) of active crude extracts was determined by broth microdilution method as described in NCCLS (1997). The test was performed in 96 wells microtiter plates, two- fold serial dilutions of all extracts and standard antibiotics were made in Cation Adjusted Muller-Hinton Broth (CAMHB) ranging from $1-512 \mu \mathrm{g} / \mathrm{ml}$. Inoculum was prepared in the same medium at a density adjusted to 0.5 McFarland standard and added $100 \mu 1$ of it to each well except negative control. The final volume in the well was $200 \mathrm{ml}$. After 24 hours of incubation at $37^{\circ} \mathrm{C}$ the MIC was calculated as the visible lowest concentration of the extract inhibiting growth of bacterial strain (Kaushik and Chauhan, 2009).

\section{Minimum Bactericidal Concentration determination}

MBC was determined by sub culturing the $5 \mu 1$ of test dilution from each well on to a nutrient agar plate and incubating further at $37^{\circ} \mathrm{C}$ for 24 hours. The complete absence of growth at applied concentration was considered as the minimum bactericidal concentration (Seric et al.,2009).

Statistical Analysis- Statistical analysis of data was carried out by using analysis of variance (one way ANOVA) followed by Zar (1999).

\section{Results and Discussion}

The four different plant extracts of Terminalia chebula with their three different concentrations i.e. 100,200 and $400 \mathrm{mg} / \mathrm{ml}$ were subjected to check the antibacterial activity of all the four fruit extracts against Escherichia coli. Aqueous extract gave no activity at the concentration of $100 \mathrm{mg} / \mathrm{ml}$ but the methanol, ethanol and acetone extracts showed $4.0 \mathrm{~mm}, 7.0 \mathrm{~mm}$ and $4.0 \mathrm{~mm}$ zone of inhibition respectively, at the concentration of $100 \mathrm{mg} / \mathrm{ml}$. At 
the concentration of $200 \mathrm{mg} / \mathrm{ml}$, all four (Aqueous, methanol, ethanol and acetone) extracts showed $2.3 \mathrm{~mm}, 6.6 \mathrm{~mm}, 10.0 \mathrm{~mm}$ and $6.0 \mathrm{~mm}$ zone of inhibition respectively. At the concentration of

$400 \mathrm{mg} / \mathrm{ml}$ all above mentioned extracts showed $3.3 \mathrm{~mm}, 10.0 \mathrm{~mm}, 14.3 \mathrm{~mm}$ and $8.0 \mathrm{~mm}$ zone of inhibition respectively and the difference was highly significant.

Thus ethanol fruit extract of Terminalia chebula
Retz. showed best activity i.e. $7.0 \mathrm{~mm}, 10.0 \mathrm{~mm}$ and $14.3 \mathrm{~mm}$ zone of inhibition at the concentration of 100,200 and $400 \mathrm{mg} / \mathrm{ml}$ respectively against E.coli (Table 1). Negative control showed no activity and Positive control (Ciprofloxacin) gave zone of inhibition at the concentration of $5 \mu \mathrm{g} / \mathrm{ml}$ was $22.0 \mathrm{~mm}$. The MIC value of Terminalia chebula ranged from $\leq 1$ to $512 \mu \mathrm{g} / \mathrm{ml}$ and the MBC value ranged from 2 to $512 \mu \mathrm{g} / \mathrm{ml}$ (Table 2).

Table 1. Antibacterial activity of different plant extracts of Terminalia chebula

\begin{tabular}{|c|c|c|c|}
\hline \multirow{3}{*}{ Plant extracts } & \multicolumn{3}{|c|}{ Effective Zone of inhibition at different concentration(mm) } \\
\hline & \multicolumn{3}{|c|}{ E.coli } \\
\hline & 100 mg/ml & 200 mg/ml & $400 \mathrm{mg} / \mathrm{ml}$ \\
\hline Aqueous extract & $0.0 \pm 0.0$ & $2.3 \pm 0.57$ & $3.3 \pm 0.57$ \\
\hline Methanol extract & $4.0 \pm 1.0$ & $6.6 \pm 0.57$ & $10.0 \pm 0.0$ \\
\hline Ethanol extract & $7.0 \pm 1.0$ & $10.0 \pm 0.0$ & $14.3 \pm 0.57$ \\
\hline Acetone extract & $\begin{array}{c}4.0 \pm 0.0 \\
(F=99, \mathrm{df}=3,8, P>0.001)\end{array}$ & $\begin{array}{c}6.0 \pm 0.0 \\
(F=177.8, d f=3,8, P>0.001)\end{array}$ & $\begin{array}{c}8.0 \pm 0.0 \\
(F=375.16, \mathrm{df}=3,8, P>0.001)\end{array}$ \\
\hline
\end{tabular}

Effective zone of inhibition $=$ Zone of inhibition - Disc diameter, $\pm=$ Standard deviation

Table 2. The MIC and MBC of Terminalia chebula against $E$ coli

\begin{tabular}{lcc}
\hline Plant extracts & $\mathrm{MIC}(\boldsymbol{\mu g} / \mathbf{m l})$ & $\mathrm{MBC}(\boldsymbol{\mu g} / \mathbf{m l})$ \\
\hline $\begin{array}{c}\text { Aqueous } \\
\text { extract }\end{array}$ & $\mathrm{ND}$ & $\mathrm{ND}$ \\
$\begin{array}{c}\text { Methanol } \\
\text { extract }\end{array}$ & 256 & 256 \\
$\begin{array}{c}\text { Ethanol } \\
\text { extract } \\
\begin{array}{c}\text { Acetone } \\
\text { extract }\end{array}\end{array}$ & 64 & 64 \\
\hline
\end{tabular}

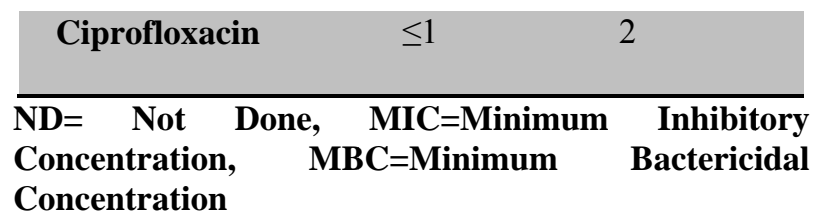

According to Johnson (1991) E. coli, though normally a gut commensal, has attracted the clinical significance owing to the recognition of several strains of diarrhoeagenic E.coli which distinct virulent factors and also an important organism in urinary tract infections (UTIs). The aqueous and ethanol extracts of Azadirachta indica has strong
(IZD $=18 \mathrm{~mm}$ and $20 \mathrm{~mm}$ ) inhibitory action against $S$. aureus but failed to show any promising (IZD $=8 \mathrm{~mm}$ or more) inhibitory effect against the Gram-negative bacteria P.aeruginosa and E.coli. The aqueous extract of T. chebula and A. marmelos showed strong (IZD $=15-23 \mathrm{~mm}$ ) inhibitory action against all the strains evaluated. The MIC value of T. chebula and A. marmelos against the test strains ranged from 1.56 to $3.12 \mathrm{mg} / \mathrm{ml}$ and 3.12 to $6.25 \mathrm{mg} / \mathrm{ml}$, respectively. The MBC values for $T$. chebula ranged from 1.56 to $6.25 \mathrm{mg} / \mathrm{ml}$ and for $A$. marmelos showed strong (IZD $=15-23 \mathrm{~mm}$ ) inhibitory action against all the strains evaluated. The MIC value of $T$. chebula and A. marmelos against the test strains ranged from 1.56 to $3.12 \mathrm{mg} / \mathrm{ml}$ and 3.12 to $6.25 \mathrm{mg} / \mathrm{ml}$, respectively. The MBC values for T. chebula ranged from 1.56 to $6.25 \mathrm{mg} / \mathrm{ml}$ and for A. marmelos from 12.50 to $50.0 \mathrm{mg} / \mathrm{ml}$ (Chattopadhyay et al., 2009). Suriya et al. (2012) worked on antibacterial activity of Abutilon indicum, Hygrophila spinosa and Mimosa pudica were studied by agar well diffusion method in vitro. 


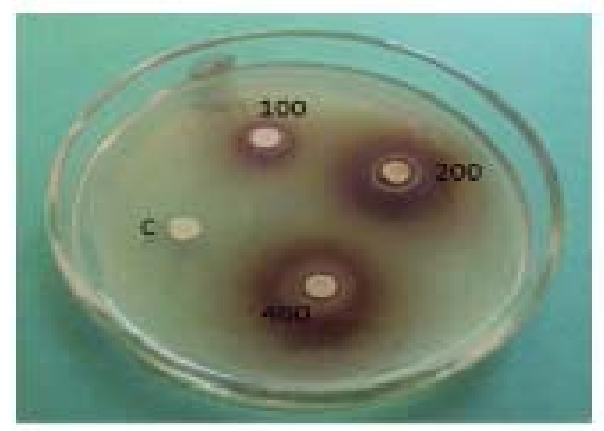

A

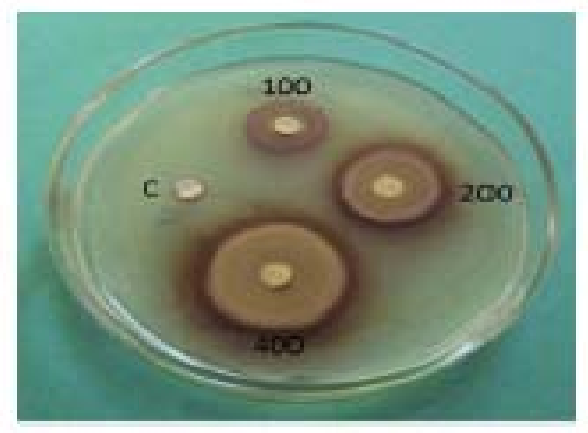

C

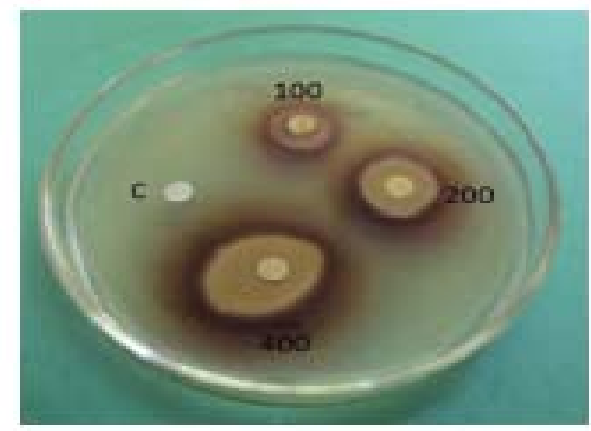

B

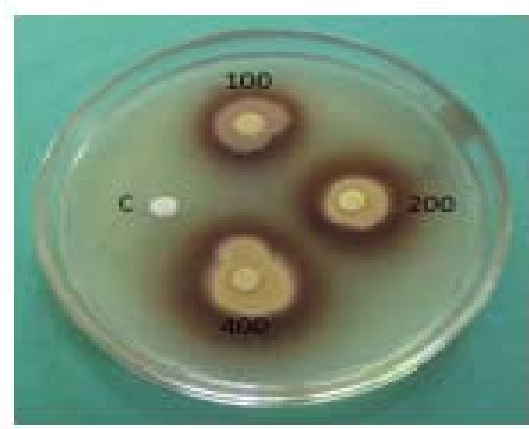

D

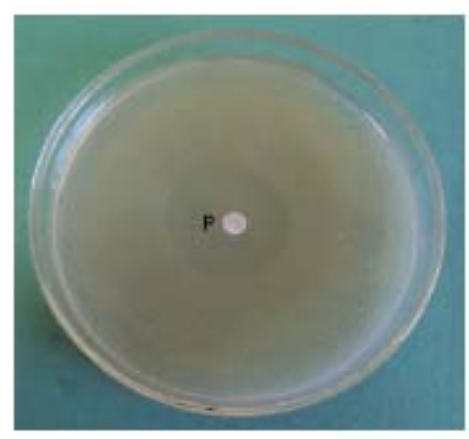

E

Zone of inhibition exhibited by different extracts of Terminalia chebula against $E$. coli

A.Aqueous extract B. Methanol extract C. Ethanol extract D. Acetone extract E. Ciprofloxacin

Petriplates: 100, 100 mg/ml; 200, 200 mg/ml; 400, 400mg/ml; C, Negative Control; P, Positive control.

The effect of antibacterial potential was examined against Escherichia coli, Pseudomonas aeruginosa, Staphylococcus aureus, Bacillus cereus, Proteus vulgaris, Enterococcus faecalis, Klebsiella pneumoniae, Vibrio cholera, Salmonella typhi and Salmonella paratyphi. The methanol extract of these medicinal plants have showed consistently significant inhibitory activity on different bacterial pathogens tested. Furthermore, the Minimum Inhibitory Concentration carried out by broth dilution assay, ranged between 0.2 to $0.9 \mathrm{mg} / \mathrm{ml}$. Overall the 
methanol extract was found more effective. The results of the extracts were compared with the standard antibiotic Kanamycin.

\section{Conclusion}

In the current investigation, the methanol, ethanol and acetone extracts of Terminalia chebula were found active but the highest antibacterial activity was observed in ethanol extract against test organism E.coli. The present study justified the claimed usage of fruits in the traditional system of medicine. However, more work is needed for better evaluation of the potential effectiveness of crude extracts as the antibacterial agents.

\section{References}

Acharyya S, Patra A and Bag K P. 2009. Evaluation of the Antimicrobial Activity of some medicinal plants against Enteric Bacteria with Particular Reference to Multi-Drug Resistant Vibrio cholerae.Tropical Journal of Pharmaceutical Research, 8(3): 231-237.

Akueshi CO, Kadiri CO, Akueshi EU, Agina SE and Ngurukwem B. 2002. Antimicrobial potentials of Hyptis sauvedens Poit (Lamiacae),Nigeria. J Bot , 15: 37-41.

Bauer AW, Kirby WMN, Sherries IC and Turk M.1966. Antibiotic susceptibility testing by a standard single disc method. AMJ.Clin Path, 45: 493.

Beyer H and Walter W.1997. Organic chemistry. $4^{\text {th }}$ ed. , Published by Jerry March, pp.146-148.

Chattopadhyay R R, Bhattacharya S K, Medd C, Chandas , Bag A. 2009. A Comparative evaluation of Antibacterial Potential of Some plants used in Indian traditional medicine for the treatment of microbial infections. Brazilian Archives of Biology and Technology, 52 (5) :1123-1128.

Dhale DA and Markandeya SK. 2011. Antimicrobial and Phytochemical Screening of Plumbago zeylanica Linn. (Plumbaginaceae) Leaf. Journal of Experimental Sciences, 2 (3): 04-06.

Erturk O, Kati H, Yayli N and Demurbau Z. 2006. Antimicrobial properties of Silene multifida(Adams) Rohrb., Plant extracts. Turk J Biol 30: 17-21.
Farombi EO. 2003. African indigenous plants with chemotherapeutic potentials and biotechnological approach to the production of bioactive prophylactic agents African Journal of Biotechnology, 2(12): 662-671.

Hooker JD.1875-1897. Flora of British India. Vol. I-VII. L.Reeve \& Co Ltd. Kent, England.

Johnson JR.1991. Virulence factor in Escherichia coli urinay tract infections. Clin Microbiology Rev, 4(1): 80-128.

Kaushik P and Chauhan A. 2009. Cynobacteria : Antibacterial Activity. New India Publishing Agency,Pitam Pura, New Delhi110088, pp. xiii+1-198.

Nataro J.P. and Kaper J.B.1998. Diarrheagenic Escherichia coli. Clin Microbiol Rev, 11 (1): 142-201.

NCCLS- National Committee for Clinical Laboratory Standard.1997a. Methods for Dilution Antimicrobial Susceptibility Tests for Bacteria that Grow Aerobically. Approved Standard M7-A4, Wayne, Pa.

Ncube NS, Afalayan AJ and Okoh A. 2008. Assessment techniques of antimicrobial properties of natural compounds of plant origin: Current methods and future trends. African Journal of Biotechnology 7(12): 17 97-1806.

Saric C L, Cabarkapa S I, Beljkas M B, Misan C A, Sakac B M, Plavsic V D. 2009. Antimicrobial activity of Plant extracts from Serbia. Food and feed Research, 36 (1-2): 1-6.

Segni L, Noureddine G, Amar Z, Labed B and Samir H. 2011. Phytochemical and Antibacterial Screening of some Algerian saharian medicinal plants. Plant sciences Feed 1(10): 179-182.

Suriya J, Raja S, Bharathi VS and Rajasekaran R. 2012. Antimicrobial activity of some medicinal herbal extracts on clinically important bacterial pathogens. IJPSR,3(2): 490-493.

Surono IS.2 004. Fermented Milk Probiotic and Healthcare. YAPMMI Jakarta, pp.1-252.

Todar K. 2008. Bacterial structure in relation to pathogenicity: The importance of the bacterial surface. http://www.textbook of bacteriology.net University of Wisconsin-Madison Department of Bacteriology, pp.1-4

Zar J H.1999. Biostatistical analysis. $4^{\text {th }}$ ed. Prentice Hall,Upper Saddle River, New Jersey, pp.662. 